\title{
The Viral Marketing (VM) Role in Directing Customer Purchasing Decisions Regarding Fast Food in Egypt
}

Mohamed .S. Ghanem

M_ghanem_@hotmail.com

The Higher Institute for Tourism, Hotels and Computer sciences, Seyouf, Alexandria

\begin{abstract}
"VM" is defined as a "recent marketing phenomenon that motivates internet users to pass marketing messages voluntarily to their relatives, colleagues and friends". The main objectives of the study can be summarized in identifying the effect of viral marketing messages' exposure, attractiveness, incentives, credibility and confidence on consumers' purchasing decisions of fast food products. Another objective is to identify the contribution of demographic factors to the activation the messages' role in purchasing decisions. Based on an analytical descriptive approach, the field research was applied to 391 participants of Internet users. The collected data were analyzed by statistical techniques of descriptive statistics and Linear Simple Regression Analysis. The results showed a statistically significant effect of exposure rate, attractiveness, incentives and degree of credibility as independent variables on purchasing decisions as a dependent variable. Other 2 variables (level of confidence among parties of viral marketing messages and demographic differences among recipients) showed insignificant effect on the purchasing decisions.
\end{abstract}

Key Words: Viral Marketing, Social Media, Customer Purchasing Decisions, Fast Food Products.

\section{Introduction}

The concept of Viral Marketing (VM) represents one of the most recent marketing concepts that reflect the transformation which occurred in marketing practices as a result of the increasing reliance on information technology, especially under the control of the Internet as an effective intermediary in the implementation of various activities (Van der Lans et al., 2010). Despite "VM" novelty as a marketing trend (Khuong and Thanh, 2016), many businesses in the developed world have begun to adopt it (Goel and Devi, 2014). The main idea of "VM" depends on sending messages and information about products (goods and services) through websites, urging users to buy these products from one side (Stewart and Ewing, 2009) and re-sending these messages and information to others from the other side to persuade them to buy those products in return for some privileges or incentives (Abedniya and Mahmouei, 2010). In this context, this research provides fast-food establishments with the overall framework of the "VM" mechanism and its impacts on the purchasing decisions of current and potential customers.

Background

\section{Viral Marketing "VM"}

Viral marketing refers to "the process of designing a self-sustaining message through rapid circulating among internet users" (Aghdaie et al., 2012). It is "the process of directing messages through the internet, so that these messages build a base of customers at a low cost by offering a prompt benefit to users that encourages them to spread the message and then recruit new customers" (Hajli et al., 2017). "VM" is therefore viewed as a "new marketing approach that motivate internet users to attract new users" (Saadeghvaziri and Hosseini, 2011; Khasawneh and Shuhair, 2013). It is a "marketing method that drives individuals to voluntarily resend their received marketing messages" (Rahimnia and Hassanzadeh, 2013; Pura, 2013; Chung et al., 2017; Jankowski et al., 2018).

\section{Purchasing Behavior and Purchasing Decisions}

Consumer purchasing behavior is "the way customers buy products that meet their needs" (Narayana et al., 2013; Ramya et al., 2017; Sathya and Indirajith, 2018). The purchasing decision is a "process for identifying options and choosing the best available alternative" (Hanaysha, 2018). Thus, while purchasing behavior is a "set of successive stages that the consumer goes through to obtain products", purchasing decision is "the final result of a series of successive stages of purchasing behavior".

\section{Number of Previous Related Studies}

Despite the recentness of e-marketing and its applications, in general, and viral marketing in particular, there is unlimited number of studies around the world conducted to address this modern phenomenon. Thus, no one can deny the attractiveness of viral marketing among marketing researchers. In 2007, Poustlchi and Wiedemann tried to rank viral marketing success factors according to their relative importance. These factors were ranked as follows: (1) The value of the product, (2) free of charge, (3) Accessibility to the product, (4) Ability to be distributed online, (5) Characteristics of viral marketing team and (6) Target groups.

In the same context, the study of Kim et al., (2009) was applied to 343 individuals exposed to viral marketing campaigns in order to determine the viral marketing success factors. The study found that the most important factors related to viral marketing success are the extent of confidence and reliability among viral message carriers, the extent of desire to share the viral message content with friends and relatives and the extent of viral message attractiveness related to providing free and encouraging offers.

To address the most reasons that drive companies to depend on viral marketing, Dasari and Akrishnan, (2010) conducted a study on a sample of young people interested in retail stores in India. Delivering promotional messages, providing new products and create brand awareness at relatively low cost are the most 3 reasons of using the viral marketing in retail stores.

The study of Seyed et al., (2012) assessed the impact of internet users' confidence on their acceptance of viral marketing. The results indicated that the confidence criterion is the most influential on users' attitude, as it leads their intention to engage in viral marketing practices.

In 2013, a study of Chohan in South Africa indicated that internet users share the content when it is attractive and consistent with the emotional aspect of them. The results confirmed that if the viral message content related to user's positive feelings, it is likely to be shared compared to the content that related to user's negative emotions. In the same context, Hirvijärvi (2017) focused on the content of viral marketing messages. The main objectives of the study were to determine how to create viral content that was attractive and influential and to identify the key elements that affect the redirection of viral content through social networks. The results indicated that the main 
reasons that drive customers to share messages through their social networking pages are: achieving social recognition, meeting emotional needs, sharing valuable or educational information, personally benefit from sharing information and expressing opinions and ideas about a certain topic. The results also indicated that marketers need to carefully identify key elements of viral marketing messages' formation to create attractive content for viral marketing campaigns on social networks.

To develop a multi-stage model of internet viral marketing, Karnell, (2003) indicated that there is a statistically significant relationship between the sender of viral message, its receiver, opening the personal website and reading the viral message. The strength of this relationship only affects the two stages of awareness and attention, thus it has no effect on the other stages of making purchasing decision. While the social dimension increases the likelihood of opening and reading viral e-mails, demographic characteristics are the only variable that statistically significantly affects all the purchasing decision-making stages.

Applied to 4 million individuals and nearly one million products, a study of Lekovec and Adamis, (2007) aimed to discover the impact of viral message sender on its receiver's purchasing decision. The study found that the role of viral marketing in increasing the sales of entertainment products; such as DVDs, musical instruments, films, songs and sports instruments as well as services is more powerful than non-entertainment goods. The results also indicated that despite the exposure to the marketing message, nearly half of the sample size $(48 \%)$ consulted their relatives and friends before purchasing electrical appliances and 50\% of the sample size used social networking to search for those products.

Fairbank (2008) aimed at assessing the effectiveness of using internet viral marketing in terms of potential sales growth and increasing brand awareness. He found that despite the variety of viral marketing techniques used to target customers, many of these techniques are not used effectively. From consumers' point of view, information provided through viral marketing campaigns is useful in making purchasing decisions. According to the results, companies need to use a variety of viral marketing techniques as they have a positive impact on potential sales growth and increase consumer awareness of the company's brand. The study also concluded that online user feedback is an effective way for companies to get valuable ideas needed to develop their products.

To examine consumer behavior in response to viral marketing in Pakistan, Irshad and Kamran, (2012) found a positive relationship between informatics, entertainment and the credibility of the source (as independent variables) from one side and the attitude towards viral marketing (as a dependent variable). From the other side, the results also confirmed that informatics and credibility of the source are the most influential features in the attitude of customers towards viral marketing.

Wei (2014) examined the impact of perceived information, entertainment, incentives and credibility of the source on the attitudes of consumers towards viral marketing in Malaysia and their intention to purchase. The results indicated a positive relationship between the incentives and attitudes of consumers towards viral marketing, while there is no statistically significant relationship between the other independent variables and the dependent variable. Moreover, the results showed that consumers' attitudes toward viral marketing affect their purchasing intent.

Francis and Alexander (2015) threw light on the promotional tactics based on wireless technologies and their impact on consumer purchasing decisions. The results indicated that the social aspects have a positive causal effect on consumers' tendency to rely on the methods of marketing via wireless technologies. Moreover, the results confirmed that the value of the offer partly works as an intermediary in influencing the consumers' reliance on viral marketing.

\section{Research Problem}

Recent marketing literature has supported the fact that "VM" has become a major part of the business world in many developed countries (Wilson, 2012). With the technological development and increased reliance on the Internet and its applications, the importance of viral marketing has emerged as a modern marketing model that can be used to promote various goods, services and ideas (Chu, 2011). Based on the previous review, the research problem was formulated in the following research questions:

- What is the effect of the exposure to viral marketing messages on the purchasing decisions related to fast food products?

- To which extent the attractiveness of the content of viral marketing messages influenced the purchasing decisions?

- What is the impact of the incentives related to viral marketing messages on the purchasing decisions?

- Is the credibility of the source of viral marketing messages influences the purchasing decisions?

- What is the influence extent of the level of confidence among senders of viral marketing messages on the purchasing decisions?

- What is the contribution of demographic factors to the activation the viral marketing messages role in the purchasing decisions of fast food products among the research sample?

\section{Research Objectives}

The main objectives of the study can be summarized as follows:

- Building a model of viral marketing factors affecting the purchasing decisions of fast food products;

- Identifying the effect of exposure to viral marketing messages on the purchasing decisions;

- Determining the impact of the attractiveness of the content of viral marketing messages on fast foods' purchasing decisions;

- Knowing the incentives impact on activating the viral marketing messages contribution to the formation of purchasing decisions;

- Examining the role of credibility of viral marketing messages' source in directing fast foods' purchasing decisions;

- Determining the impact of the level of confidence among senders of viral marketing messages on the purchasing decisions of fast food products;

- Identifying the contribution of demographic factors to activating the viral marketing messages role in purchasing decisions.

Research Importance

The need of the study becomes evidence after careful examination of current marketing literature that showed scarcity of studies on viral marketing in the Arab region, especially in Egypt. Therefore, the current study provides a 
theoretical framework related to the concept of viral marketing and the means of applying it that may attract the attention of researchers in the future towards the subject of the study and lead to further applied studies related to viral marketing and its influence on all the fields of the hospitality industry.

In addition to the scientific importance of the research, there is a practical importance related to the topic of the research. This practical importance can be highlighted through the following points:

- Decisions to develop and market various products in the contemporary world of business must be based primarily on modern methods (Kaplan and Haenlein, 2011) in order to understand how these techniques affect the purchasing behaviors of existing and potential customers (Larson, 2009).

- The adoption of modern businesses of viral marketing provides a clear explanation of how businesses have changed in response to shifts in the thinking of clients in this decade (Mindcomet Corporation, 2008). It highlights the need for enterprises to operate in different way (Rice, 2010), adopt modern approaches and marketing methods in order to achieve the development and sustainability of the success (Richardson and Domingos, 2012).

- Understanding the way customers make purchasing decisions influenced by modern marketing techniques and viral marketing can be a watershed in the process of anticipating and formulating a customer choice model (Wampole, 2012) to rely on this model later in order to judge the effectiveness of the marketing model itself, and then develop it whenever necessary.

Research Hypotheses Formulation

The Rate of Exposure to Viral Marketing Messages

Despite the multiplicity of studies that have demonstrated the role of increasing the rate of exposure to viral marketing messages through social media sites in making purchase decisions (Dasari and Akrishnan, 2010), this relationship is not based on the launch, as a number of other factors interfere in determining the degree and level of this relationship (Lekovec and Adamis, 2007). Thus, the $1^{\text {st }}$ hypothesis of the research was formulated as follows:

\section{$\mathrm{H}_{1}$ : Increasing the rate of exposure to viral marketing messages related to fast food products via social media sites affects purchasing decisions of these products.}

Attractiveness of Viral Marketing Message Contents

The degree of attractiveness of the content of a viral marketing message is one of the most important factors that interfere with the recipient's desire to share the content of that message with friends and relatives, and then spread that message among users of social networks (Kim et al., 2009). The emotional impact of the attractiveness of viral marketing content may be the cornerstone of this marketing success. While both Irshad and Kamran (2012) and Wei (2014) indicated a little impact of the attractiveness of viral marketing message content on the attitude of consumers towards this modern marketing style and therefore on the purchasing decisions, the research results of Chohan (2013) and Christian (2014) indicated that internet users share messages with the most attractive content(Christian, 2014), thus, there is a need for marketers to pay attention to the attractiveness of viral marketing content to create attractive and effective viral content for viral marketing campaigns (Hirvijärvi, 2017). According to this previous discussion, the $2^{\text {nd }}$ hypothesis is formulated as follows:

\section{H2: The attractiveness of the content of viral marketing messages related to fast food} products affects the purchasing decisions of these products.

\section{Incentives Related to Passing Viral Marketing Messages}

Companies have effective strategies to attract customers to use their websites and pass the viral message by offering free and attractive offers (Kim et al., 2009). Christian (2014) suggests that consumer behavior related to viral marketing messages is heavily influenced by motivations. Wei (2014) noted a positive correlation between incentives and consumer attitudes towards viral marketing. Francis and Alexander (2015) also emphasized that the value of incentives and offers to users works partly as an intermediary influencing the likelihood of consumers relying on viral marketing when making purchasing decisions. In context with that, the third hypothesis of the research was formulated as follows:

H3: The incentives involved in passing viral marketing messages related to fast food products
affects the purchasing decisions of these products.
The Level of Credibility of the Source of Viral Marketing Messages

The credibility of the information contained in the viral marketing messages sent through the websites is of great importance because it can be relied upon as a primary source of identification of the product and its characteristics. Therefore, it is responsible for the formation of a positive image of the sending organization (Hamed, 2017). Based on this, the $4^{\text {th }}$ hypothesis of the research his formulated as follows:

\section{$\mathrm{H}_{4}$ : The degree of credibility of the source of viral marketing messages related to fast food} products affects the purchasing decisions of these products.

The level of confidence among the senders of viral marketing messages

Kim et al. (2009) highlighted the importance of the level of confidence among viral message parties in directing purchase decisions. Irshad and Kamran (2012) confirmed that consumer behavior, as a reaction to viral marketing messages, was influenced by the level of confidence among this message parties. In line with this, the $5^{\text {th }}$ hypothesis of the research was formulated as follows:

\section{H5: The level of confidence among parties of viral marketing messages related to fast food} products affects the purchasing decisions of these products.

\section{The Demographic Characteristics of Consumers}

Karnell, (2003) indicated that demographic characteristics are the only ones that have a statistically significant effect on all stages of purchasing decision making, beginning with the desire to open and read the viral marketing message, through all stages of interaction with that message and ending with purchase or non-purchase decision. Thus, the difference of gender, age, education level and monthly income of consumers lead to the difference in the impact of viral marketing message on their purchase decisions. Accordingly, the $6^{\text {th }}$ hypothesis of the research was formulated as follows:

\section{H6: Demographic characteristics differences among recipients of viral marketing message} related to fast food products affect the purchasing decisions of these products. 
To test this main hypothesis, a number of sub-hypotheses were formulated as follows:

- $\mathrm{H}_{6 \mathrm{~A}}$ : Age group difference among recipients of viral marketing message related to fast food products affects the purchasing decisions of these products among the research sample.

- $\mathrm{H}_{6 \mathrm{~B}}$ : Gender difference affects the purchasing decisions.

- $\mathrm{H}_{6 \mathrm{C}}$ : Education level difference affects the purchasing decisions.

- $\mathrm{H}_{6 \mathrm{D}}$ : Household income level difference affects the purchasing decisions.

\section{Research Variables}

According to the research hypotheses, variables can be classified as follows:

Independent Variables

- The rate of exposure to viral marketing messages.

- Attractive content of viral marketing messages.

- Incentives involved in passing viral marketing messages.

- Degree of credibility of the source of viral marketing messages.

- The level of confidence among parties of viral marketing messages.

- Demographic characteristics of recipients of viral marketing messages.

The dependent variable

It is the purchase decisions among the research sample.

Based on these different variables, the research proposed a model the can be illustrated in figure (1).

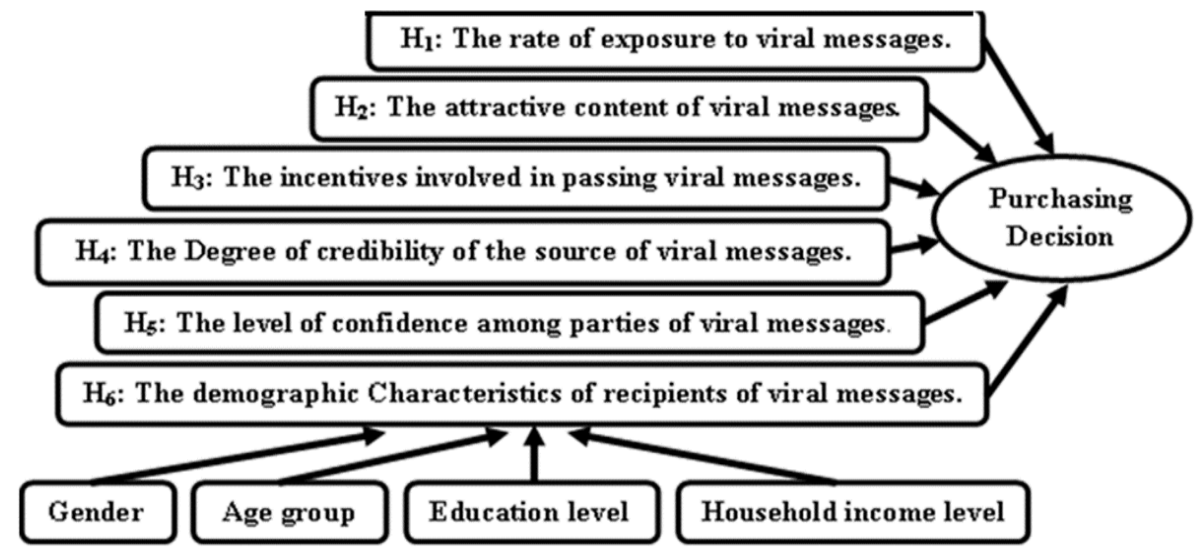

Figure (1): The Proposed Model of the Research

Research Methodology

(Source: Prepared by the Author based on the research hypotheses).

The study is based on an analytical descriptive approach to describe the role of viral marketing in directing the purchasing decisions of fast food products among the research sample members and to test the research hypotheses. Depending on likert scale, a questionnaire was designed and developed to collect data from the sample. Based on the statistical analysis of the relative weight of questionnaire points, the coefficient of validity of the questionnaire is 0.921, which means that the scale is valid. According to the analysis of the Cronbach Alpha coefficient for the questionnaire stability, the results showed that the coefficient stability is 0.959 , which strongly indicates the stability of the questionnaire.

The field research was applied to a sample of Internet users. While 2156 questionnaires were distributed, 514 questionnaires were returned during a period of one month. By checking the received questionnaires, only 391 were completed and valid for analysis. The collected data were analyzed by using PASW Statistics version 18. Statistical techniques of descriptive statistics and Linear Simple Regression Analysis were used to achieve the research objectives.

Results

Data Presentation Sample

Demographic Characteristics of Research

As shown in table (1), 54.2\% of respondents were from 20 to less than 35 years, about half of them are males $(52.2 \%)$, the highest percentage of them is highly educated $(80.3 \%)$ and the majority of them $(41.7 \%)$ are with an income level ranging between 4500 to less than 6000 L.E.

Table (1): Research Sample Profile

\begin{tabular}{|c|c|c|c|c|c|}
\hline Demographics & Choices & $\begin{array}{c}F \\
391 \\
\end{array}$ & $\begin{array}{c}\% \\
100 \\
\end{array}$ & Mean & Std. Deviation \\
\hline \multirow{5}{*}{ Age Group } & Under 20 Years & 88 & 22.5 & \multirow{5}{*}{2.19} & \multirow{5}{*}{1.041} \\
\hline & 20 to $<35$ Years & 212 & 54.2 & & \\
\hline & 35 to $<45$ Years & 40 & 10.2 & & \\
\hline & 45 to $<60$ Years & 30 & 7.7 & & \\
\hline & 60 Years and more & 21 & 5.4 & & \\
\hline \multirow{2}{*}{ Gender } & Male & 204 & 52.2 & \multirow{2}{*}{1.48} & \multirow{2}{*}{0.500} \\
\hline & Female & 187 & 47.8 & & \\
\hline \multirow{3}{*}{ Education Level } & Intermediate education and less & 24 & 6.1 & \multirow{3}{*}{2.74} & \multirow{3}{*}{0.561} \\
\hline & Upper intermediate education & 53 & 13.6 & & \\
\hline & High education & 314 & 80.3 & & \\
\hline \multirow{4}{*}{$\begin{array}{l}\text { Monthly Household } \\
\text { Income Level }\end{array}$} & Less than 3000 L. E & 45 & 11.5 & \multirow{4}{*}{3.04} & \multirow{4}{*}{0.964} \\
\hline & 3000 to $<4500$ L. E & 38 & 9.7 & & \\
\hline & 4500 to $<6000$ L. E & 163 & 41.7 & & \\
\hline & More than $6000 \mathrm{~L} . \mathrm{E}$ & 145 & 37.1 & & \\
\hline
\end{tabular}


The General Impact of Viral Marketing on Purchasing Decisions

Depending on data illustrated in table (2), the majority of respondents $(60.3 \%)$ indicated that their purchasing decisions of fast food products are influenced by viral marketing messages.

Table (2): The General Impact of Viral Marketing on Purchasing Decisions

\begin{tabular}{|c|c|c|c|c|c|c|c|c|c|c|}
\hline \multirow{2}{*}{ Sentences } & \multicolumn{2}{|c|}{$\begin{array}{c}\text { Strongly } \\
\text { Agree }\end{array}$} & \multicolumn{2}{|c|}{ Agree } & \multicolumn{2}{|c|}{ Neutral } & \multicolumn{2}{c|}{ Disagree } & \multicolumn{2}{c|}{$\begin{array}{c}\text { Strongly } \\
\text { Disagree }\end{array}$} \\
\cline { 2 - 10 } & $\mathrm{F}$ & $\%$ & $\mathrm{~F}$ & $\%$ & $\mathrm{~F}$ & $\%$ & $\mathrm{~F}$ & $\%$ & $\mathrm{~F}$ & $\%$ \\
\hline $\begin{array}{l}\text { In general, my purchasing decisions } \\
\text { related to fast food products are } \\
\text { influenced by viral marketing } \\
\text { messages. }\end{array}$ & 110 & 28.1 & 126 & 32.2 & 75 & 19.2 & 59 & 15.1 & 21 & 5.4 \\
\hline
\end{tabular}

\section{The Rate of Exposure to Viral Marketing Messages}

With regard to fast food products as shown in table 3, the highest percentage of respondents $(79.3 \%)$ referred that they are recently exposed to more viral marketing messages through social media. The majority of them $(72.8 \%)$ indicated that their purchases of fast food products had increased recently. Most of them $(70.6 \%)$ confirmed that they depend on information included in the viral messages in making purchasing decisions. In the same context, they referred that, the viral messages encourage them to eat those products more and more $(68.6 \%)$. They linked the increase of their purchasing rates of such products during the last 3 months with the increase of exposure rates of viral marketing during the same period $(66.8 \%)$ as they feel a desire to eat fast food whenever they are exposed to viral marketing messages $(68.3 \%)$.

Table (3): The Rate of Exposure to the Viral Marketing Messages

\begin{tabular}{|c|c|c|c|c|c|c|c|c|c|c|}
\hline \multirow{2}{*}{ Sentences } & \multicolumn{2}{|c|}{$\begin{array}{l}\text { Strongly } \\
\text { Agree }\end{array}$} & \multicolumn{2}{|c|}{ Agree } & \multicolumn{2}{|c|}{ Neutral } & \multicolumn{2}{|c|}{ Disagree } & \multicolumn{2}{|c|}{$\begin{array}{l}\text { Strongly } \\
\text { Disagree }\end{array}$} \\
\hline & $\bar{F}$ & $\%$ & $\mathrm{~F}$ & $\%$ & $\mathrm{~F}$ & $\%$ & $\mathrm{~F}$ & $\%$ & $\bar{F}$ & $\%$ \\
\hline $\begin{array}{l}\text { With regard to fast food, I think that I am } \\
\text { exposed to more viral marketing } \\
\text { messages through social media recently. }\end{array}$ & 177 & 45.3 & 133 & 34 & 39 & 10 & 35 & 9 & 7 & 1.8 \\
\hline $\begin{array}{l}\text { My purchase of fast food has increased } \\
\text { recently. }\end{array}$ & 155 & 39.6 & 130 & 33.2 & 49 & 12.5 & 45 & 11.5 & 12 & 3.1 \\
\hline $\begin{array}{l}\text { The information included in the viral } \\
\text { messages help me in making purchasing } \\
\text { decisions. }\end{array}$ & 147 & 37.6 & 129 & 33 & 50 & 12.8 & 52 & 13.3 & 13 & 3.3 \\
\hline $\begin{array}{l}\text { The Viral messages make me want to eat } \\
\text { those products more and more. }\end{array}$ & 141 & 36.1 & 127 & 32.5 & 53 & 13.6 & 56 & 14.3 & 14 & 3.6 \\
\hline $\begin{array}{l}\text { I think that the number of times I eat fast } \\
\text { foods at the last } 3 \text { months was influenced } \\
\text { by the frequency of related viral } \\
\text { marketing messages. }\end{array}$ & 143 & 36.6 & 125 & 32 & 57 & 14.6 & 52 & 13.3 & 14 & 3.6 \\
\hline $\begin{array}{l}\text { I feel a desire to eat fast food whenever I } \\
\text { am exposed to related viral marketing } \\
\text { messages. }\end{array}$ & 140 & 35.8 & 127 & 32.5 & 54 & 13.8 & 56 & 14.3 & 14 & 3.6 \\
\hline
\end{tabular}

\section{The Attractive Content of Viral Marketing Messages}

Depending on the data of table (4), the majority of respondents $(66.3 \%)$ are attracted by the content of viral messages of fast food product that encouraged them to purchase those products as they refereed that they had already purchased many fast food products because of their attractive image in viral videos $(66.5 \%)$. To confirm this, $69 \%$ of the respondents are tending to pass fast food viral marketing messages to their friends and relatives if the content of these messages are interesting and appealing, 70\% of them have no objection to spread viral messages as long as they are funny and $54.4 \%$ of them are already sharing many fast food viral marketing videos through social media recently.

Table (4): The Attractive Content of Viral Marketing Messages

\begin{tabular}{|c|c|c|c|c|c|c|c|c|c|c|}
\hline \multirow[t]{2}{*}{ Sentences } & \multicolumn{2}{|c|}{$\begin{array}{l}\text { Strongly } \\
\text { Agree }\end{array}$} & \multicolumn{2}{|c|}{ Agree } & \multicolumn{2}{|c|}{ Neutral } & \multicolumn{2}{|c|}{ Disagree } & \multicolumn{2}{|c|}{$\begin{array}{l}\text { Strongly } \\
\text { Disagree }\end{array}$} \\
\hline & $\bar{F}$ & $\%$ & $\bar{F}$ & $\%$ & $\bar{F}$ & $\%$ & $\bar{F}$ & $\%$ & $\bar{F}$ & $\%$ \\
\hline $\begin{array}{l}\text { The Attractive content of viral messages } \\
\text { of fast food product encourages me to } \\
\text { purchase these products. }\end{array}$ & 136 & 34.8 & 123 & 31.5 & 57 & 14.6 & 58 & 14.8 & 17 & 4.3 \\
\hline $\begin{array}{l}\text { I have already purchased many fast food } \\
\text { products because of their attractive image } \\
\text { in the viral videos. }\end{array}$ & 136 & 34.8 & 124 & 31.7 & 56 & 14.3 & 58 & 14.8 & 17 & 4.3 \\
\hline $\begin{array}{l}\text { I tend to pass fast food viral marketing } \\
\text { messages to my friends and relatives } \\
\text { whenever the content of these messages } \\
\text { are interesting and appealing. }\end{array}$ & 140 & 35.8 & 130 & 33.2 & 58 & 14.8 & 49 & 12.5 & 14 & 3.6 \\
\hline $\begin{array}{l}\text { I have no objection to spread viral } \\
\text { messages as long as they are funny. }\end{array}$ & 139 & 35.5 & 135 & 34.5 & 58 & 14.8 & 47 & 12 & 12 & 3.1 \\
\hline $\begin{array}{l}\text { Recently, I have already shared many fast } \\
\text { food viral marketing videos through social } \\
\text { media. }\end{array}$ & 92 & 23.5 & 121 & 30.9 & 87 & 22.3 & 73 & 18.7 & 18 & 4.6 \\
\hline
\end{tabular}




\section{Incentives Involved in Passing Viral Marketing Messages}

In line with the data in table (5) the majority of respondents $(94.2 \%)$ are more likely to pass fast food viral messages as their preference of specific product increases with the viral messages that involve incentives $(66.5 \%) ; 94.2 \%$ of them confirmed that when they benefited from an offer they tend to pass this message to other relatives and colleagues to benefit from it. Not only that, but in many times, more than half of them $(54 \%)$ tend to eat a particular fast food product as a result of provided incentives included in its viral marketing messages.

Table (5): Incentives Involved in Passing Viral Marketing Messages

\begin{tabular}{|c|c|c|c|c|c|c|c|c|c|c|}
\hline \multirow{2}{*}{ Sentences } & \multicolumn{2}{|c|}{ Strongly Agree } & \multicolumn{2}{|c|}{ Agree } & \multicolumn{2}{|c|}{ Neutral } & \multicolumn{2}{|c|}{ Disagree } & \multicolumn{2}{|c|}{$\begin{array}{l}\text { Strongly } \\
\text { Disagree }\end{array}$} \\
\hline & $\mathrm{F}$ & $\%$ & $\mathrm{~F}$ & $\%$ & $\mathrm{~F}$ & $\%$ & $\mathrm{~F}$ & $\%$ & $\mathrm{~F}$ & $\%$ \\
\hline $\begin{array}{l}\text { I am more likely to pass fast food viral } \\
\text { messages if tangible or intangible } \\
\text { incentives are offered. }\end{array}$ & 211 & 54 & 157 & 40.2 & 18 & 4.6 & 5 & 1.3 & 0 & 0 \\
\hline $\begin{array}{l}\text { My preference of specific fast food } \\
\text { product increases if its viral messages } \\
\text { involve incentives. }\end{array}$ & 136 & 34.8 & 124 & 31.7 & 57 & 14.6 & 59 & 15.1 & 15 & 3.8 \\
\hline $\begin{array}{l}\text { When I benefited from an offer related to } \\
\text { fast food viral message, I tend to pass this } \\
\text { message to my relatives and colleagues to } \\
\text { benefit from it. }\end{array}$ & 211 & 54.0 & 157 & 40.2 & 18 & 4.6 & 5 & 1.3 & 0 & 0 \\
\hline $\begin{array}{l}\text { In many times, I go to eat a particular fast } \\
\text { food product as a result of the provided } \\
\text { incentives included in its viral marketing } \\
\text { messages. }\end{array}$ & 88 & 22.5 & 123 & 31.5 & 88 & 22.5 & 73 & 18.7 & 19 & 4.9 \\
\hline
\end{tabular}

\section{Credibility of the Source of Viral Marketing Messages}

As shown in table (6), while the majority of respondents (67.2\%) trust in offers and information about fast food products via viral marketing messages, the percentage of those who agree (42\%) and who disagree (41.2) to share and pass these messages, regardless of its sources, are fairly equals. In the same context, while $66 \%$ of them may care about fast food viral marketing messages that pass to them from people they do not know, more than half $(53.7 \%)$ confirmed that they don't purchase any new fast food product depending on viral messages that come from new sites.

Table (6): Credibility of the Source of Viral Marketing Messages

\begin{tabular}{|l|c|c|c|c|c|c|c|c|c|c|}
\hline \multirow{2}{*}{ Sentences } & \multicolumn{2}{|c|}{ Strongly Agree } & \multicolumn{2}{|c|}{ Agree } & \multicolumn{2}{c|}{ Neutral } & \multicolumn{2}{c|}{ Disagree } & \multicolumn{2}{c|}{$\begin{array}{c}\text { Strongly } \\
\text { Disagree }\end{array}$} \\
\cline { 2 - 12 } & $\mathrm{F}$ & $\%$ & $\mathrm{~F}$ & $\%$ & $\mathrm{~F}$ & $\%$ & $\mathrm{~F}$ & $\%$ & $\mathrm{~F}$ & $\%$ \\
\hline $\begin{array}{l}\text { I trust in offers and information about fast } \\
\text { food products that come to me via viral } \\
\text { marketing messages. }\end{array}$ & 130 & 33.2 & 133 & 34.0 & 60 & 15.3 & 47 & 12 & 21 & 5.4 \\
\hline $\begin{array}{l}\text { I do not mind to share and pass any fast } \\
\text { food viral marketing message regardless } \\
\text { of its source. }\end{array}$ & 77 & 19.7 & 87 & 22.3 & 66 & 16.9 & 127 & 32.5 & 34 & 8.7 \\
\hline $\begin{array}{l}\text { I may care about fast food viral marketing } \\
\text { messages that pass to me from people I do } \\
\text { not know. }\end{array}$ & 126 & 32.2 & 132 & 33.8 & 60 & 15.3 & 49 & 12.5 & 24 & 6.1 \\
\hline $\begin{array}{l}\text { I don't purchase any new fast food } \\
\text { product depending on viral messages that } \\
\text { come from new sites. }\end{array}$ & 99 & 25.3 & 111 & 28.4 & 76 & 19.4 & 72 & 18.4 & 33 & 8.4 \\
\hline
\end{tabular}

The Level of Confidence among Parties of Viral Marketing Messages

Examining the data in table (7), the majority of respondents $(68.6 \%)$ indicated that it isn't necessary to know the person who send viral message to re-pass it as they have no objection to interact with fast food viral marketing messages that come from persons they don't know (66.7\%). However, it is different when it comes to purchasing the product, as $63.4 \%$ of them referred to that their purchasing decisions are not influenced by viral marketing message directed from new persons and there are no chances of experiencing new fast food products unless a viral message comes from their close persons $(63.4 \%)$

Table (7): The Level of Confidence among Parties of Viral Marketing Messages

\begin{tabular}{|c|c|c|c|c|c|c|c|c|c|c|}
\hline \multirow[t]{2}{*}{ Sentences } & \multicolumn{2}{|c|}{$\begin{array}{c}\text { Strongly } \\
\text { Agree }\end{array}$} & \multicolumn{2}{|c|}{ Agree } & \multicolumn{2}{|c|}{ Neutral } & \multicolumn{2}{|c|}{ Disagree } & \multicolumn{2}{|c|}{$\begin{array}{l}\text { Strongly } \\
\text { Disagree }\end{array}$} \\
\hline & $\mathrm{F}$ & $\%$ & $\mathrm{~F}$ & $\%$ & $\bar{F}$ & $\%$ & $\mathrm{~F}$ & $\%$ & $\bar{F}$ & $\%$ \\
\hline $\begin{array}{l}\text { To re-pass fast food viral marketing } \\
\text { message, it is necessary to know the } \\
\text { person who send me this message. }\end{array}$ & 41 & 10.5 & 30 & 7.7 & 52 & 13.3 & 195 & 49.9 & 73 & 18.7 \\
\hline $\begin{array}{l}\text { It is rarely to interact with fast food } \\
\text { viral marketing messages that come } \\
\text { from persons I don't know. }\end{array}$ & 42 & 10.7 & 34 & 8.7 & 54 & 13.8 & 189 & 48.3 & 72 & 18.4 \\
\hline $\begin{array}{l}\text { My purchasing decisions related to } \\
\text { fast food products are not influenced } \\
\text { by viral marketing message directed } \\
\text { from new persons. }\end{array}$ & 122 & 31.2 & 126 & 32.2 & 67 & 17.1 & 52 & 13.3 & 24 & 6.1 \\
\hline $\begin{array}{l}\text { The chances of experiencing new fast } \\
\text { food products increased when the } \\
\text { related viral message was passed from } \\
\text { my close person. }\end{array}$ & 122 & 31.2 & 126 & 32.2 & 67 & 17.1 & 52 & 13.3 & 24 & 6.1 \\
\hline
\end{tabular}




\section{Data Analysis}

Data analysis is summarized in the test of research hypotheses as follows:

$\mathrm{H}_{1}$ : Increasing the Rate of Exposure to Viral Marketing Messages Related to Fast Food Products Affects Purchasing Decisions of These Products

By using Linear Simple Regression Analysis, the results showed a statistically significant effect $(\mathrm{P}-\mathrm{value}=0.000)$ of the independent variable (Exposure rate to viral messages) on the dependent variable (Purchasing decisions). This means that any increase of the former will positively affect the latter (Table 8). By calculating Regression Coefficient $(\beta=0.219)$, the results indicated that any increase of the exposure rate by one unit will positively affect the purchasing decisions by 0.219 unit. According to this significant effect, the research accepts the $1^{\text {st }}$ hypothesis.

Table (8): Linear Simple Regression Analysis of Data Related to the $\mathbf{1}^{\text {st }}$ Hypothesis

\begin{tabular}{|c|c|c|c|c|c|c|}
\hline \multirow{2}{*}{ Statement } & \multirow{2}{*}{$\begin{array}{c}\mathrm{R} \\
\text { Coefficient of } \\
\text { correlation }\end{array}$} & \multirow{2}{*}{$\begin{array}{c}\mathrm{R}^{2} \\
\text { The coefficient of } \\
\text { determination }\end{array}$} & \multirow{2}{*}{$\mathrm{F}$} & \multirow{2}{*}{ Sig. } & \multicolumn{2}{|c|}{$\begin{array}{c}\beta \\
\text { Regression Coefficient }\end{array}$} \\
\hline & & & & & Variable & Coefficient \\
\hline Influences of Viral & & & & 0.000 & Constant & 2.770 \\
\hline $\begin{array}{l}\text { marketing on fast food } \\
\text { products' purchasing } \\
\text { decisions }\end{array}$ & 0.196 & 0.038 & 15.565 & 0.000 & $\begin{array}{c}\text { Exposure } \\
\text { rate to viral } \\
\text { messages }\end{array}$ & 0.219 \\
\hline
\end{tabular}

$\mathrm{H}_{2}$ : The Attractiveness of the Content of Viral Marketing Messages Related to Fast Food Products Affects the Purchasing Decisions of These Products

According to data illustrated in table (9), the results of Linear Simple Regression Analysis showed a statistically significant effect (P-value $=0.000)$ of the independent variable (Attractive content of viral messages) on the dependent variable (Purchasing decisions). This means that the increase of attractiveness of viral marketing messages will positively affect the purchasing decisions. By calculating Regression Coefficient $(\beta=0.249)$, the results indicated that any increase of the attractiveness of viral marketing messages by one unit will positively affect the purchasing decisions by 0.249 unit. According to this significant effect, the research accepts the $2^{\text {nd }}$ hypothesis.

Table (9): Linear Simple Regression Analysis of Data Related to the $2^{\text {nd }}$ Hypothesis

\begin{tabular}{|c|c|c|c|c|c|c|}
\hline \multirow[t]{2}{*}{ Statement } & \multirow{2}{*}{$\begin{array}{c}\mathrm{R} \\
\text { Coefficient of } \\
\text { correlation }\end{array}$} & \multirow{2}{*}{$\begin{array}{c}\mathrm{R}^{2} \\
\text { The coefficient of } \\
\text { determination }\end{array}$} & \multirow[t]{2}{*}{$\mathrm{F}$} & \multirow[t]{2}{*}{ Sig. } & \multicolumn{2}{|c|}{$\begin{array}{c}\beta \\
\text { Regression Coefficient }\end{array}$} \\
\hline & & & & & Variable & Coefficient \\
\hline \multirow[b]{2}{*}{$\begin{array}{c}\text { Influences of Viral } \\
\text { marketing on fast food } \\
\text { products' purchasing } \\
\text { decisions }\end{array}$} & \multirow[b]{2}{*}{0.201} & \multirow[b]{2}{*}{0.040} & \multirow[b]{2}{*}{16.347} & 0.000 & Constant & 2.691 \\
\hline & & & & 0.000 & $\begin{array}{l}\text { Attractive } \\
\text { content of } \\
\quad \text { viral } \\
\text { messages }\end{array}$ & 0.249 \\
\hline
\end{tabular}

H3: $_{3}$ The Incentives Involved in Passing Viral Marketing Messages Related to Fast Food Products Affect the Purchasing Decisions of These Products

Depending on the data of table (10), Linear Simple Regression Analysis results showed a statistically significant effect $(\mathrm{P}$-value $=0.000)$ of the independent variable (Incentives involved in passing viral messages) on the dependent variable (Purchasing decisions). By calculating Regression Coefficient $(\beta=0.390)$, the results indicated that any increase of viral marketing messages incentives by one unit will positively affect the purchasing decisions by 0.390 unit. According to this significant effect, the research accepts the $3^{\text {rd }}$ hypothesis.

Table (10): Linear Simple Regression Analysis of Data Related to the $3^{\text {rd }}$ Hypothesis

\begin{tabular}{|c|c|c|c|c|c|c|}
\hline Statement & $\begin{array}{c}\mathrm{R} \\
\text { Coefficient of } \\
\text { correlation }\end{array}$ & $\begin{array}{c}\text { The coefficient of } \\
\text { determination }\end{array}$ & $\mathrm{F}$ & \multirow{2}{*}{ Sig. } & \multicolumn{2}{|c|}{\begin{tabular}{c} 
Regression Coefficient \\
\cline { 5 - 7 }
\end{tabular}} \\
\hline $\begin{array}{c}\text { Influences of Viral } \\
\text { marketing on fast food } \\
\text { products' purchasing } \\
\text { decisions }\end{array}$ & 0.197 & 0.039 & 15.741 & 0.000 & $\begin{array}{c}\text { Variable } \\
\text { Coefficient } \\
\text { involved in } \\
\text { passing viral } \\
\text { messages }\end{array}$ & 0.390 \\
\hline
\end{tabular}

$\mathrm{H}_{4}$ : The Degree of Credibility of the Source of Viral Marketing Messages Related to Fast Food Products Affects the Purchasing Decisions of These Products

By using Linear Simple Regression Analysis as shown in table (11), there is a statistically significant effect (P-value $=0.001)$ of the independent variable (Credibility of viral messages' source) on the dependent variable (Purchasing decisions). Regression Coefficient $(\beta=0.189)$, indicated that any increase of the credibility level by one unit will positively affect the purchasing decisions by 0.189 unit. According to this significant effect, the research accepts the $4^{\text {th }}$ hypothesis.

Table (11): Linear Simple Regression Analysis of Data Related to the $4^{\text {th }}$ Hypothesis

\begin{tabular}{|c|c|c|c|c|c|c|}
\hline \multirow[t]{2}{*}{ Statement } & \multirow{2}{*}{$\begin{array}{c}\mathrm{R} \\
\text { Coefficient of } \\
\text { correlation }\end{array}$} & \multirow{2}{*}{$\begin{array}{c}\mathrm{R}^{2} \\
\text { The coefficient of } \\
\text { determination }\end{array}$} & \multirow[t]{2}{*}{$\mathrm{F}$} & \multirow[t]{2}{*}{ Sig. } & \multicolumn{2}{|c|}{$\begin{array}{c}\beta \\
\text { Regression Coefficient }\end{array}$} \\
\hline & & & & & Variable & Coefficient \\
\hline \multirow[b]{2}{*}{$\begin{array}{c}\text { Influences of Viral } \\
\text { marketing on fast food } \\
\text { products' purchasing } \\
\text { decisions }\end{array}$} & \multirow[b]{2}{*}{0.171} & \multirow[b]{2}{*}{0.029} & \multirow[b]{2}{*}{11.692} & 0.000 & Constant & 2.961 \\
\hline & & & & 0.001 & $\begin{array}{l}\text { credibility of } \\
\text { viral } \\
\text { messages' } \\
\text { source }\end{array}$ & 0.189 \\
\hline
\end{tabular}

H5: The Level of Confidence among Parties of Viral Marketing Messages Related to Fast Food Products Affects the Purchasing Decisions of These Products

According to Table (12), the results of Linear Simple Regression Analysis showed no statistical significant effect (P-value $=0.589)$ of the independent variable (confidence among parties of viral messages) on the dependent 
variable (Purchasing decisions). This means that increasing the confidence level among parties of viral marketing messages related to fast food product via social media sites will not affect the purchasing decisions of such products among research participants. According to this insignificant effect, the research rejects the $5^{\text {th }}$ hypothesis.

Table (12): Linear Simple Regression Analysis of Data Related to the $5^{\text {th }}$ Hypothesis

\begin{tabular}{|c|c|c|c|c|c|c|}
\hline \multirow[t]{2}{*}{ Statement } & \multirow{2}{*}{$\begin{array}{c}\mathrm{R} \\
\text { Coefficient of } \\
\text { correlation }\end{array}$} & \multirow{2}{*}{$\begin{array}{c}\mathrm{R}^{2} \\
\text { The coefficient of } \\
\text { determination }\end{array}$} & \multirow[t]{2}{*}{$\mathrm{F}$} & \multirow[t]{2}{*}{ Sig. } & \multicolumn{2}{|c|}{$\begin{array}{c}\beta \\
\text { Regression Coefficient }\end{array}$} \\
\hline & & & & & Variable & Coefficient \\
\hline \multirow{2}{*}{$\begin{array}{l}\text { Influences of Viral marketing } \\
\text { on fast food products' } \\
\text { purchasing decisions }\end{array}$} & \multirow[t]{2}{*}{0.027} & \multirow[t]{2}{*}{0.001} & \multirow[t]{2}{*}{0.293} & 0.000 & Constant & 3.369 \\
\hline & & & & 0.589 & $\begin{array}{c}\text { confidence } \\
\text { among parties of } \\
\text { viral messages }\end{array}$ & 0.084 \\
\hline
\end{tabular}

H6: Demographic Characteristics Differences among Recipients of Viral Marketing Message Related to Fast Food Products Affect the Purchasing Decisions of These Products

To test this main hypothesis, a number of sub-hypotheses were tested as follows:

$\mathrm{H}_{6 \mathrm{~A}}$ : Age group difference among recipients of viral marketing message related to fast food products affects the purchasing decisions of these products

According to Table (13), the results of Linear Simple Regression Analysis showed no statistical significant effect of $(\mathrm{P}$-value $=0.776)$ of age group difference as an independent variable on the purchasing decisions as a dependent variable (Regression Coefficient- $\beta=0$. 017). According to this insignificant effect, the research rejects this subhypothesis.

\begin{tabular}{|c|c|c|c|c|c|c|}
\hline \multirow{2}{*}{ Statement } & \multirow{2}{*}{$\begin{array}{c}\mathrm{R} \\
\text { Coefficient of } \\
\text { correlation }\end{array}$} & \multirow{2}{*}{$\begin{array}{c}\mathrm{R}^{2} \\
\text { The coefficient of } \\
\text { determination }\end{array}$} & \multirow{2}{*}{$\mathrm{F}$} & \multirow{2}{*}{ Sig. } & \multicolumn{2}{|c|}{$\begin{array}{c}\beta \\
\text { Regression Coefficient }\end{array}$} \\
\hline & & & & & Variable & Coefficient \\
\hline \multirow{8}{*}{$\begin{array}{l}\text { Influences of Viral } \\
\text { marketing on fast } \\
\text { food products' } \\
\text { purchasing decisions }\end{array}$} & \multirow{2}{*}{0.014} & \multirow{2}{*}{0.000} & \multirow{2}{*}{0.081} & 0.000 & Constant & 3.590 \\
\hline & & & & 0.776 & Age & 0.017 \\
\hline & \multirow{2}{*}{0.021} & \multirow{2}{*}{0.000} & \multirow{2}{*}{0.167} & 0.000 & Constant & 3.553 \\
\hline & & & & 0.683 & Gender & 0.049 \\
\hline & \multirow{2}{*}{0.014} & \multirow{2}{*}{0.000} & \multirow{2}{*}{0.079} & 0.000 & Constant & 3.709 \\
\hline & & & & 0.779 & Education & -0.030 \\
\hline & \multirow{2}{*}{0.095} & \multirow{2}{*}{0.009} & \multirow{2}{*}{3.549} & 0.000 & Constant & 3.985 \\
\hline & & & & 0.060 & Income & -0.118 \\
\hline
\end{tabular}

H$_{6 \mathrm{~B}}$ : Gender difference among recipients of viral marketing message related to fast food products affects the purchasing decisions of these products

The Linear Simple Regression Analysis results (Table13) showed no statistically significant effect of $(\mathrm{P}$-value $=$ 0.683 ) of gender difference as an independent variable on the purchasing decisions as a dependent variable (Regression Coefficient- $\beta=0.049$ ). According to this insignificant effect, the research rejects this sub-hypothesis.

HoC $_{6}$ : Education level difference among recipients of viral marketing message related to fast food products affects the purchasing decisions of these products

Back to table (13), the Linear Simple Regression Analysis results showed no statistical significant effect $(\mathrm{P}-\mathrm{value}=$ 0.779 ) of education level difference as an independent variable on the purchasing decisions as a dependent variable (Regression Coefficient- $\beta=-0.030$ ). According to this insignificant effect, the research rejects this sub-hypothesis.

$H_{6 D}$ : Household income level difference among recipients of viral marketing message related to fast food products affects the purchasing decisions of these products

The Linear Simple Regression Analysis results (Table13) showed no statistically significant effect of $(\mathrm{P}$-value $=$ 0.060) of household income level difference as an independent variable on the purchasing decisions as a dependent variable (Regression Coefficient- $\beta=-0.118$ ). Accordingly, the research rejects this sub-hypothesis.

Rejecting all the 4 sub-hypotheses related to the $6^{\text {th }}$ main hypothesis means that there is no effect of demographic characteristics' differences on the purchasing decisions of such products. Thus, the research rejects wholly the $6^{\text {th }}$ main hypothesis.

Table (14) and Figure (2) summarize all the research results related.

Table (14): Summary of Research Hypotheses

\begin{tabular}{|c|c|c|c|c|c|}
\hline \multicolumn{3}{|c|}{ Hypotheses } & $\beta$ & Sig. & Result \\
\hline $\mathrm{H}_{1}$ & \multicolumn{2}{|c|}{$\begin{array}{l}\text { Increasing the rate of exposure to viral marketing messages related to fast food } \\
\text { products via social media sites affects purchasing decisions of these products. }\end{array}$} & 0.219 & 0.000 & Supported \\
\hline $\mathrm{H}_{2}$ & \multicolumn{2}{|c|}{$\begin{array}{l}\text { The attractiveness of the content of viral marketing messages related to fast } \\
\text { food products affects the purchasing decisions of these products. }\end{array}$} & 0.249 & 0.000 & Supported \\
\hline $\mathrm{H}_{3}$ & \multicolumn{2}{|c|}{$\begin{array}{l}\text { The incentives involved in passing viral marketing messages related to fast } \\
\text { food products affects the purchasing decisions of these products. }\end{array}$} & 0.390 & 0.000 & Supported \\
\hline $\mathrm{H}_{4}$ & \multicolumn{2}{|c|}{$\begin{array}{l}\text { The degree of credibility of the source of viral marketing messages related to } \\
\text { fast food products affects the purchasing decisions of these products. }\end{array}$} & 0.189 & 0.001 & Supported \\
\hline $\mathrm{H}_{5}$ & \multicolumn{2}{|c|}{$\begin{array}{l}\text { The level of confidence among parties of viral marketing messages related to } \\
\text { fast food products affects the purchasing decisions of these products. }\end{array}$} & 0.589 & 0.084 & Rejected \\
\hline \multirow{4}{*}{$\mathrm{H}_{6}$} & \multirow{4}{*}{$\begin{array}{l}\text { Demographic characteristics differences among recipients of } \\
\text { viral marketing message related to fast food products affect } \\
\text { the purchasing decisions of these products among the } \\
\text { research sample. }\end{array}$} & Age & 0.017 & 0.776 & Rejected \\
\hline & & Gender & 0.049 & 0.683 & Rejected \\
\hline & & Education & -0.030 & 0.779 & Rejected \\
\hline & & Income & -0.118 & 0.060 & Rejected \\
\hline
\end{tabular}


Research Model

Figure (2) briefs the relationships among various variables.

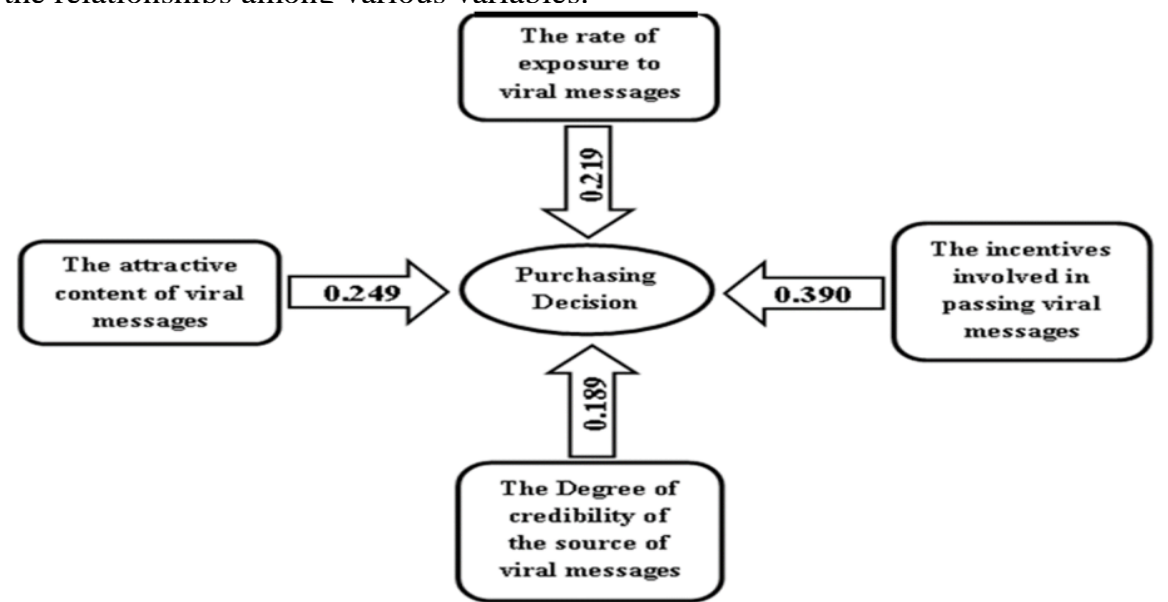

Figure (2): Relationships among variables

Research Limitations

(Source: Prepared by the Author based on the research results).

This research is related only to 391 participants and caution. The results are confined to viral marketing messages that promote fast food products. This means that these results couldn't be generalized to any other food products offered by various types of hospitality outlets and establishments.

\section{Recommendations}

- The adoption of new marketing applications is no longer an option, but it is an inevitable necessity of penetrating the markets. Egyptian enterprises working in the field of fast food should take advantage of modern marketing techniques to achieve a market share that demonstrates their strong presence on the market.

- Establishments engaged in the provision of fast food products should work to activate and develop viral

\section{References} marketing messages that correspond to the needs of the new generation of social network users.

- Abedniya, A. and Mahmouei, S. S. (2010). "The impact of social networking websites to facilitate the effectiveness of viral marketing", International Journal of Advanced Computer Science and Applications, 1(6): 139-146.

- Aghdaie, S. F.; Sanayei, A. and Etebari, M. (2012). "Evaluation of the Consumers' Trust Effect on Viral Marketing Acceptance Based on the Technology Acceptance Model". International Journal of Marketing Studies, 4(6): 79-94

- Bartlett, J. E.; Kotrlik, J. W. and Higgins, C. C. (2001). "Organizational Research: Determining Appropriate Sample Size in Survey Research". Information Technology, Learning, and Performance Journal, 19(1): 43-50.

- Borges, B. (2009). "Marketing 2.0 Bridging the Gap Between Seller and Buyer Through Social Media Marketing", Wheatmark.

- Chohan, R. (2013). "Understanding the role of emotion in viral marketing", A Master Thesis of Business Science, Marketing Section, School of Management Studies, University of Cape Town, $15^{\text {th }}$ November.

- Chu, S-C. (2011). "Viral Advertising in Social Media: Participation in Facebook Groups and Responses among College-Aged Users". Journal of Interactive Advertising. Last retrieved at 25 February 2019 from: (http://dx.doi.org/10.1080/15252019.2011.10722189).

- Chung, A. Q.; Andreev, P.; Benyoucef, M.; Duane, A. and O’Reilly, P. (2017). "Managing an organisation's social media presence: An empirical stage of growth model". International Journal of Information Management, 37(1): 1405-1417.

- Dasari, S. and Akrishnan, B. (2010). "Viral Marketing Products: A study on the influence of Attributes of web portals and Incentives offered on user Registrations", IUP Journal of Marketing Management, 9(1/2): 99-112.

- Francis, K. O. and Alexander, B. (2015). "Promotional Tactics for Online Viral Marketing Campaigns: How Scarcity and Personalization Affect Seed Stage Referrals", Journal of Interactive Marketing 32(C): 37-52.

- Goel, D. and Devi, G. (2014). "A review on impact of viral marketing," Global Journal of Multidisciplinary Studies, 3(3), 119-127.

- Hajli, N.; Shanmugam, M.; Papagiannidis, S.; Zahay, D. and Richard, M. O. (2017). "Branding co-creation with members of online brand communities". Journal of Business Research, 70, 136-144.

- Hamed, E. M. (2017). "Investigating Effects of Viral Marketing on Consumer's Purchasing Dscision: Case Study: The Students of The Administrative Sciences College- Najran University", British Journal of Marketing Studies, 5(4), 63-73.

- Hanaysha, J. R. (2018) "An examination of the factors affecting consumer's purchase decision in the Malaysian retail market", PSU Research Review, 2(1): 7-23.

- Hirvijärvi, F. (2017). "Viral Marketing and content forwarding on social media: Outlining the key elements behind successful viral content creation", Master Thesis, International Business Arcada - University of Applied Sciences.

- Kaplan, A. M. and Haenlein, M. (2011). "Two hearts in three-quarter time: How to waltz the social media/viral marketing". Business Horizons, 54(3): 58-93.

- Khasawneh, M. A. and Shuhaiber, A. (2013). "A comprehensive model of factors influencing consumer attitudes towards and acceptance of SMS advertising: an empirical Investigation in Jordan". International Journal of Sales and Marketing Management, 3(2): 1-22. 
- Khuong, M. N. and Thanh, T. T. (2016). "The Impacts of Viral Marketing on Vietnamese Travelers Decision to Thailand - A Study in Ho Chi Minh City", Vietnam International Journal of Innovation, Management and Technology, 7(5): 200-205.

- Larson, R. J. (2009). "The rise of viral marketing through the new media of social media". Faculty Publications and Presentations. Paper 6. Last retrieved at 25 February 2019from: (http://digitalcommons.liberty.edu/busi_fac_pubs/6).

- Mindcomet Corporation - white paper. (2008). "Viral marketing: Understanding the concepts and benefits of viral marketing". Last retrieved at $25^{\text {th }}$ of February 2019from: (http://cmginteractive.com/uploads/viral_marketing.pdf).

- Narayana, L.; Samal, A. S. and Rao, N. P. (2013). "A study on consumer buying behavior towards organized and unorganized retail store, International Journal of management research and business strategy, 2(3):35-46.

- Pura, K. (2013). "Effectiveness of Online Marketing Tools", Degree in Management from the NOVA - School of Business and Economics, 1-25.

- Rahimnia, F. and Hassanzadeh, J. F. (2013). "The impact of website content dimension and e-trust on e-marketing effectiveness: The case of Iranian commercial saffron corporations", Information and Management, 5(5): 240247.

- Ramya, N.; Ali, M. and Bhuvaneshwari, A. (2017). "A study of consumer buying behaviour in departmental store with special reference to Coimbatore city", International Journal of Applied Research, 3(3): 734-737.

- Rice, D. (2010). "Managing your reputation in a viral world". Last retrieved at 25 February 2019from: (http://search.proquest.com/docview/228394652).

- Richardson, M. and Domingos, P. (2012)." Evolving viral marketing strategies". Last retrieved at 25 February 2019from: (http://dl.acm.org/citation.cfm?id=1830701).

- Saadeghvaziri, F. and Hosseini, H.K. (2011), "Mobile Advertising: An Investigation of Factors Creating Positive Attitude in Iranian Customers", African Journal of Business Management, 5(2): 394-404.

- Sathya, P. and Indirajith, R. (2018). "A Study on Purchase Behavior of Consumer Durable Goods with Special Reference to Tiruvarur District". International Journal of Scientific Research and Management, 6(2): 100-107.

- Seyed, A.; Amiri, F.; Sanayei, A. and Etebari, M. (2012). "Evaluation of the Consumers' Trust Effect on Viral Marketing Acceptance Based on the Technology Acceptance Model", International Journal of Marketing Studies, 4(6): 114-126

- Stewart, D. B. and Ewing, M. T. (2009). “A Conceptual Framework for Viral Marketing, ANZMAC, 207-216.

- Taherdoost, H. (2017). "Determining Sample Size; How to Calculate Survey Sample Size". International Journal of Economics and Management Systems, 2, 237-239.

- Van der Lans, R.; van Bruggen, G.; Eliashberg, J. and Wierenga, J. (2010). "A Viral Branching Model for Predicting the Spread of Electronic Word of Mouth". Marketing Science, 29(2): 348-365.

- Wampole, H. (2012). "Viral marketing: An online spin to traditional word of mouth advertising". Last retrieved at 25 February 2019from: (www.honors.ufl.edu/apps/Thesis.aspx/Download/1302).

- Wei, L. S. (2014). "The Attitudes of Consumers towards Viral Marketing in Malaysia", Unpublished Master Thesis, Department of International Business, Faculty of Accountancy and Management, University of Tunku Abdul Rahman, April, Malaysia.

- Wilson, R. F. (2012). "The six simple principles of viral marketing". Last retrieved at 25 February 2019from: (http://www.gwu.edu/ ibus266j/Global\%20E-marketing/031300_viral.html).

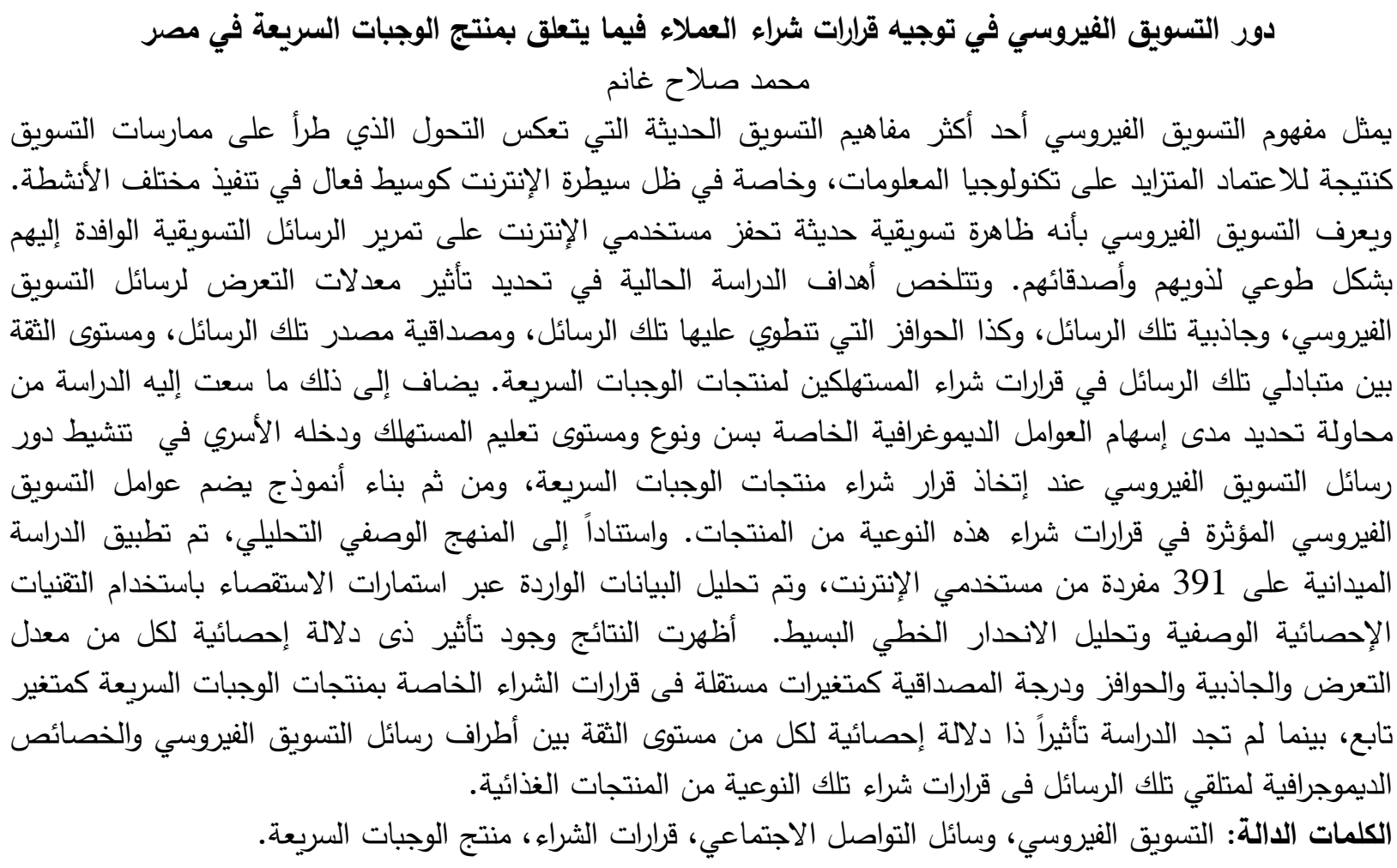

